\title{
Microbiological quality of frozen black mussels (Mytilus galloprovincialis, Lamarck, 1819) purchased from markets in the İzmir Province of Turkey
}

\section{Türkiye'nin İzmir ilinde marketlerden satın alınan dondurulmuş kara midyelerin (Mytilus galloprovincialis, Lamarck, 1819) mikrobiyolojik kalitesi}

\section{Bülent Kafa ${ }^{1}$ • Berna Kılınç}

${ }^{1}$ Food Control Department, Izmir/Bornova Veterinary Control Institute, Bornova-Izmir, Turkey

${ }^{2}$ Ege University, Fisheries Faculty, Fish Processing Technology Department, Bornova-Izmir, Turkey

D https://orcid.org/0000-0002-1402-894X (D) https://orcid.org/0000-0002-4663-5082

\section{How to cite this paper:}

Kafa, B. \& Kilınç, B. (2021). Microbiological quality of frozen black mussels (Mytilus galloprovincialis, Lamarck, 1819) purchased from markets in the İzmir Province of Turkey. Ege Journal of Fisheries and Aquatic Sciences, 38(2), 167-172. DOI: 10.12714/egejfas.38.2.05

\begin{abstract}
The purpose of this study was to examine the microbiological quality and consumer safety of frozen black mussels purchased from four different markets $(A, B, C, D)$ in the İzmir Province of Turkey. A total of 36 frozen black mussel packages, which contained approximately 50 mussels in each, were purchased from the markets. They were not only examined for total mesophilic, psychrotrophic, coliform and fecal coliform bacteria count but also investigated for pathogenic bacteria such as Escherichia coli, Staphylococcus aureus, Listeria monocytogenes and Vibrio spp. According to the results of the mesophilic bacteria counts, frozen black mussels did not exceed the microbiological limits set for safe consumption. The findings showed that frozen black mussels purchased from (A, B, C, D) of markets were safe for human consumption because pathogenic bacteria species such as E.coli, Salmonella spp., S. aureus, L. monocytogenes and Vibrio spp. were not present in the frozen mussel samples.
\end{abstract}

Keywords: Frozen black mussel, microbiological quality, safety, pathogenic bacteria

Öz: Bu çalışmanın amacı Türkiye' nin İmir ilinde dört farkı marketten (A, B, C, D) satın alınan dondurulmuş kara midyelerin güvenliğini ve mikrobiyal kalitesini belirlemektir. Bu amaçla dört farklı marketten her biri yaklaşık 50 adet dondurulmuş kara midye içeren toplam 36 paket satın alınmıştır. Dondurulmuş kara midyeler sadece toplam mezofilik, psikrotrofik, koliform, fekal koliform açısından değil, aynı zamanda Escherichia coli, Staphylococcus aureus, Listeria monocytogenes, Vibrio türleri gibi patojenik bakteriler içinde incelenmiş̧ir. Bulgularımız, Türkiye' nin İzmir ilindeki dört farklı marketten (A, B $C, D)$ satın alınarak incelenen dondurulmuş kara midyelerin, E. coli, S. aureus, L. monocytogenes ve Vibrio spp. gibi patojenik bakteri türlerini içermemesi nedeniyle, insan tüketimi için güvenli olduğunu göstermiştir.

Anahtar kelimeler: Dondurulmuş kara midye, mikrobiyolojik kalite, güvenlik, patojen bakteri

\section{INTRODUCTION}

Seafoods are main source of protein, vitamins, minerals and essential fatty acids. Many beneficial effects of seafoods on human health have been given by many authors (Lund, 2013; Tahergorabi and Jaczynski, 2016; Spiller et al., 2019). Chemical and microbiological contaminants in fisheries products could be a risk for human health (Jovic and Stankovic, 2014; Robert-Pillot et al., 2014; Nicolas et al., 2017; Zahelyazkov et al., 2018; Alvarez-Munoz et al., 2018; Liu et al., 2018; Farady, 2019; Hallström et al., 2019). Although hygienic and heath safety regulations are in place to minimize such risks, microbiological contaminants can still occur, either through lack of coastal marine environmental quality or through the processing and marketing chain (KIIInç and Besler, 2014). Mussels are benthic filter feeders that can accumulate chemical pollutants, microplastics, microorganisms and toxins from phytoplankton blooms etc. (Witte et al., 2014). Robert-Pillot et al. (2014) indicated that seafood consumption presented a potential risk to human health in France and also in their findings the authors highlighted the importance of tools for a preventive consumer protection policy. The safety of various seafoods varies according to the origin of the fishery products, microbiological ecology of the product, contamination level, handling, processing practices and preparations before consumption (KIIInç and Besler, 2014). Many studies have been done about the shelf life of mussels stored under refrigerated conditions (Manousaridis et al., 2005; Erkan 2005; Caglak et al., 2008; Bongiorno et al., 2018; Tosun et al., 2018). In addition to this; many studies have been done about the microbiological quality of seafood products (Huss, 1997; Ripabelli et al., 1999; Papadopoulou et al., 2007; CruzRomero et al., 2008; Lampila and McMillin, 2012; RobertPillot et al., 2014; Okpola, 2014; Turan et al., 2013; Turan and Onay, 2015; Kocatepe et al., 2016; KIlınç et al., 2018; Kocatepe et al., 2019). However, in the literature there is limited study found about examining the microbiological 
quality and safe for human consumption of frozen mussels (Popovic et al., 2010; Georgescu et al., 2015; Angane et al., 2020). For this reason, the aim of this study was to examine the microbiological quality of frozen black mussels purchased from four different markets in the İzmir, Turkey.

\section{MATERIAL AND METHODS}

\section{Frozen black mussel material}

A total of 36 frozen mussel packages, including nine packages from each market were purchased from four different markets ( $A, B, C$ and $D)$ in different locations in the İzmir Province. Following their collection from markets, samples were immediately brought to the laboratory under hygienic conditions in cooler box by using ice in approximately 30 minutes. The number of mussels contained in each frozen package ranged from 45 to 59 individuals. The total mussel weight in each package was $500 \mathrm{~g}$ (Table 1).

Table 1. The number of frozen black mussels in each package purchased from four different markets

\begin{tabular}{lllll}
\hline $\begin{array}{l}\text { Frozen Black } \\
\text { mussel packages }\end{array}$ & A & B & C & D \\
\hline 1 & 53 & 52 & 52 & 47 \\
2 & 47 & 49 & 47 & 51 \\
3 & 45 & 52 & 47 & 50 \\
4 & 52 & 48 & 51 & 49 \\
5 & 53 & 49 & 47 & 49 \\
6 & 51 & 52 & 47 & 52 \\
7 & 46 & 49 & 47 & 59 \\
8 & 59 & 47 & 48 & 49 \\
9 & 57 & 49 & 49 & 49 \\
\hline
\end{tabular}

Total number of mussels sampled: $n=1800$. The avarage number of mussels in all packages: $n=50 \pm 3.32$. The total weight of mussels in a per package: $500 \pm 0.00 \mathrm{~g}$

\section{Microbiological analyses}

Each black mussel package was homonized by using stomacher (IUL, Barcelona, Spain) for $1 \mathrm{~min}$, before microbiological evaluation. Microbiological tests were performed by using TS EN ISO 6887-2 method after the preparation of samples, initial suspension and decimal dilutions (Anonymus, 2001). Mesophilic and psychrotrophic aerobic bacteria counts were done according to the method described in ISO 4833-1:2013. Total mesophilic aerobic bacteria counts were done by using the pour plate method on plate count agar (PCA, Liofilchem, Italy). After the inoculation, petri dishes were incubated at $30 \pm 1^{\circ} \mathrm{C}$ for $72 \mathrm{~h}$ according to method of TS ISO 4833-1:2013. Thereafter all colonies on plate count agar were counted and converted into log cfu/g. For determining total psychrotrophic aerobic bacteria count, plate count agar (PCA, Liofilchem, Italy) was also used. The inoculated petri dishes were incubated at $2-8^{\circ} \mathrm{C}$ for 7 days were given as log cfu/g (Anonymous, 2013) Total coliform, fecal coliform and E.coli analyses were done according to TS ISO 7251:2015 procedure. Lauryl Sulfate Tryptose Broth
(LSTB), EC Broth, and Tryptone Broth were used to determine of coliform, fecal coliform and E.coli, respectively, according to the Most Probable Number (MPN) method. Coliform bacteria growth and gas production were qualitatively determined (positive/negative). The tubes were incubated at $37^{\circ} \mathrm{C} \pm 1^{\circ} \mathrm{C}$ for $24-48 \mathrm{~h}$ for coliform bacteria analysis. For confirmation, Brilliant Green Bile Broth (BGBB) was used as controls. Total coliforms were given as MPN/g. One loopful was taken from the positive tubes and inoculated into the EC Broth containing tubes. These tubes were incubated at $44^{\circ} \mathrm{C} \pm 1^{\circ} \mathrm{C}$ for $24 \pm 2 \mathrm{~h}$ for determining fecal coliform bacteria. After the incubation period, one loopful was taken from the positive tubes and inoculated into the Tryptone Broth. These tubes were incubated at $44^{\circ} \mathrm{C} \pm 1^{\circ} \mathrm{C}$ for $48 \pm 2 \mathrm{~h}$ for $E$. coli analysis. After the indol test, the tubes with positive results were given as $E$. coli MPN/g (Anonymous, 2015). The analysis of Salmonella species was investigated by using TS EN ISO 6579 method. Pre-enrichment was conducted from $25 \mathrm{~g}$ of samples were diluted in $225 \mathrm{ml}$ of buffered peptone water and incubated at $37^{\circ} \mathrm{C}$ for 24 hours. Secondary selective enrichment was performed in Rappaport-Vassiliadis Soy Broth at $37^{\circ} \mathrm{C}$ for $24 \mathrm{~h}$ and Muller-Kaufmann tetrathionate broth with Novobiocin at $37^{\circ} \mathrm{C}$ for $24 \mathrm{~h}$, and plating on XLD agar and Rambach agar, XLT-4 agar at $37^{\circ} \mathrm{C}$ for $24 \mathrm{~h}$. (Anonymous, 2005). The analysis of Listeria monocytogenes was performed according to the method of ISO 11290-1. Listeria Enrichment Broth Base Fraser was prepared Fraser by adding the respective supplements. Pre-enrichment was conducted in Half Fraser Broth for $24 \mathrm{~h}$ at $30^{\circ} \mathrm{C}$. Then, the primary and secondary enrichment tubes were inoculated onto Oxford and ALOA agar(Agar Listeria Ottaviani and Agosti) and incubated at $37^{\circ} \mathrm{C}$ for 48 hours (Anonymous, 1997). Baird parker agar with Rabbit Fibrinogen were used for the coagulase positive Staphyloccocci according to method of TS 6582-2 EN ISO 6888-2 (Anonymous, 2006). The analysis of the samples by Real-Time PCR for Vibrio species were done according to the method of Dupont Q7 BAX system analysis kit Dupont, BAX Part D12863877 (Anonymous, 2016).

\section{Statistical analysis}

All statistical analyses were carried out by using the SPSS 25.0 (IBM-SPSS, USA) Software Package Program of Social Sciences. The homegenicity of the bacterial counts of group variances were tested by using the Levene test (Gamgam and Altunkaynak, 2017) to distinguish differences between markets. The goodness of fit of the dependent variable to the normal distribution was controlled by Kolmogorov-Smirnov and Shapiro-Wilk methods, described in (Gamgam and Altunkaynak, 2017). Kruskal-Wallis test was performed from nonparametric tests (Gamgam and Altunkaynak, 2017) as the dependent variable for the market did not provide the normality assumption. Mann-Whitney test was also used for determining the differences of bacteria counts between the markets (Gamgam and Altunkaynak, 2017). The level of significance was represented as $p<0.05$. 


\section{RESULTS}

Total mesophilic aerobic bacteria count (TMBC) (log cfu/g) of frozen black mussels purchased from four different markets are given in Table 2. The average mean values of TMBC of all packages $(n=36)$ were found as $2.42 \mathrm{log} \mathrm{cfu} / \mathrm{g}$.

Group variances on the basis of markets for the TMBC as the dependent variable were found to be homogeneous according to the Levene test. The goodness of fit of the dependent variable to the normal distribution was tested by using the Kolmogorov-Smirnov and Shapiro-Wilk methods (Gamgam and Altunkaynak, 2017). Kruskal - Wallis test was also performed from nonparametric tests as the dependent variable for the markets did not provide the normality assumption and the test result was not statistically significant $(p>0.05)$. According to the method of (Gamgam and Altunkaynak, 2017). The average value of TMBC did not differ significantly $(p>0.05)$ between markets. According to ICMSF (1992); the upper acceptable limit for TMBC of mussels is 5.0 $\log$ cfu/g. In our study examined 36 packages from four different markets were not exceeded this limit.

Total psychrotrophic bacteria counts (TPBC) (log cfu/g) of the packages are given in Table 2.The average mean values of TPBC for all samples were found to be $2.57 \mathrm{log}$ cfu/g. Group variances between markets were not homogeneous for the psychrotrophic dependent variable (Levene test, Kolmogorov-Smirnov and Shapiro-Wilk tests) described in (Gamgam and Altunkaynak, 2017). The assumption of homogenity was not found. So, Kruskal-Wallis test showed statistical significance ( $p$-value $=0.001$ ). Thus, the average number of TPBC varies significantly between markets. According to the Mann-Whitney test, the psychrotrophic average value for market $A$ differs significantly $(p<0.05)$ from all other market averages ( $p$-values: $A$ and $B=0.031$, p-values: $A$ and $C=0.000, p$-values: $A$ and $D=0.000$ ), the difference between other market averages was not significant ( $p>0.05$ ). ( $p$-values: $B$ and $C=0.387, p$-values: $B$ and $D=0.094$, $p$-values: $C$ and $D=0.222$ ). In another words, no significant differences $(p>0.05)$ were determined in TPBC of mussel samples of $B, C$ and $D$.

No significant differences $(p>0.05)$ were determined in TMBC of frozen black mussels between the four different markets $(A, B, C, D)$ as well as no significant differences $(p>0.05)$ were determined in TPBC of frozen samples for the markets $(B, C$ and $D)$, but this difference was found statistically significant $(p<0.05)$ for the market $A$.

In our study total coliform bacteria (TCB), fecal coliform bacteria (FCB), S. aureus, E.coli, Salmonella spp., Listeria monocytogenes and Vibrio spp. were not determined in any of frozen mussel samples which were purchased from four different markets in İzmir, Turkey (Table 2).
Table 2. Microbiological quality of frozen black mussels purchased from four different markets

\begin{tabular}{|c|c|c|c|c|}
\hline & TMBC & TPBC & TCB & FCB \\
\hline \multicolumn{5}{|c|}{$\mathbf{A}$} \\
\hline 1 & 2.34 & 2.65 & $<3.0$ & $<3.0$ \\
\hline 2 & 2.38 & 2.66 & $<3.0$ & $<3.0$ \\
\hline 3 & 2.36 & 2.62 & $<3.0$ & $<3.0$ \\
\hline 4 & 2.34 & 2.63 & $<3.0$ & $<3.0$ \\
\hline 5 & 2.46 & 2.67 & $<3.0$ & $<3.0$ \\
\hline 6 & 2.47 & 2.64 & $<3.0$ & $<3.0$ \\
\hline 7 & 2.34 & 2.66 & $<3.0$ & $<3.0$ \\
\hline 8 & 2.38 & 2.63 & $<3.0$ & $<3.0$ \\
\hline 9 & 2.46 & 2.64 & $<3.0$ & $<3.0$ \\
\hline \multicolumn{5}{|l|}{ B } \\
\hline 1 & 2.44 & 2.55 & $<3.0$ & $<3.0$ \\
\hline 2 & 2.46 & 2.56 & $<3.0$ & $<3.0$ \\
\hline 3 & 2.43 & 2.61 & $<3.0$ & $<3.0$ \\
\hline 4 & 2.34 & 2.66 & $<3.0$ & $<3.0$ \\
\hline 5 & 2.44 & 2.68 & $<3.0$ & $<3.0$ \\
\hline 6 & 2.46 & 2.59 & $<3.0$ & $<3.0$ \\
\hline 7 & 2.36 & 2.55 & $<3.0$ & $<3.0$ \\
\hline 8 & 2.43 & 2.56 & $<3.0$ & $<3.0$ \\
\hline 9 & 2.46 & 2.59 & $<3.0$ & $<3.0$ \\
\hline \multicolumn{5}{|l|}{ C } \\
\hline 1 & 2.38 & 2.55 & $<3.0$ & $<3.0$ \\
\hline 2 & 2.44 & 2.55 & $<3.0$ & $<3.0$ \\
\hline 3 & 2.43 & 2.59 & $<3.0$ & $<3.0$ \\
\hline 4 & 2.46 & 2.61 & $<3.0$ & $<3.0$ \\
\hline 5 & 2.38 & 2.56 & $<3.0$ & $<3.0$ \\
\hline 6 & 2.44 & 2.62 & $<3.0$ & $<3.0$ \\
\hline 7 & 2.41 & 2.50 & $<3.0$ & $<3.0$ \\
\hline 8 & 2.46 & 2.53 & $<3.0$ & $<3.0$ \\
\hline 9 & 2.49 & 2.63 & $<3.0$ & $<3.0$ \\
\hline \multicolumn{5}{|c|}{ D } \\
\hline 1 & 2.41 & 2.61 & $<3.0$ & $<3.0$ \\
\hline 2 & 2.46 & 2.62 & $<3.0$ & $<3.0$ \\
\hline 3 & 2.49 & 2.34 & $<3.0$ & $<3.0$ \\
\hline 4 & 2.39 & 2.20 & $<3.0$ & $<3.0$ \\
\hline 5 & 2.46 & 2.56 & $<3.0$ & $<3.0$ \\
\hline 6 & 2.50 & 2.54 & $<3.0$ & $<3.0$ \\
\hline 7 & 2.56 & 2.37 & $<3.0$ & $<3.0$ \\
\hline 8 & 2.46 & 2.59 & $<3.0$ & $<3.0$ \\
\hline 9 & 2.36 & 2.43 & $<3.0$ & $<3.0$ \\
\hline
\end{tabular}

$\mathrm{n}=36$; the mean value \pm standard deviation of TMBC and TPBC of frozen samples: $2.42 \pm 0.05$ and $2.57 \pm 0.09$. S. aureus, E.coli, Vibrio spp., L. monocytogenes, Salmonella spp. were not present

\section{DISCUSSION}

Lampila and McMillin (2012) reported in their study that seafood had very highly perishable product. Another author also reported that they can be contaminated with pathogens such as Staphylococcus aureus, Listeria monocytogenes, Salmonella and Vibrio species etc. (Huss, 1997). For this reason, the importance of detection, identification and monitoring of these pathogenic bacteria in seafood was highlighted by the authors that was critical in achieving the seafood safety goals (Ripabelli et al., 1999; Cruz- Romero et al., 2008; Arvanitoyannis and Stratakos, 2010; Okpala, 2014; 
Bavisett et al., 2018). According to The Turkish Food Codex Regulation on Microbiological Criteria No. 28157 dated December 29, 2011, V. cholerae and V. parahaemolyticus should not be present in fishery products that are grown/caught from salt water. Microbiological criteria for mussel samples in the notification criteria in Turkey also indicated that Salmonella spp. and L. monocytogenes should not be present in 25 grams of the sample according to (Communiqué on microbiological criteria in Turkey, 2011). In lights of above literatures, frozen black mussels purchased from the markets $A, B, C, D$ in the İzmir Province of Turkey were safe for human consumption because pathogenic bacteria species such as E. coli, Salmonella spp., S. aureus, L. monocytogenes and Vibrio spp. were not present in the frozen samples.

Shelf-life studies were done about mussels which were packaged in different packages and stored at different temperatures. In one report the authors reported that under the current commercial practice, live mussels only had 10 days' shelf life (Odeyemi et al., 2018). Erkan (2005) indicated that the shelf-life of mussels at $4^{\circ} \mathrm{C}$ was limited to 4 days.

The authors reported in the below studies that the processing and packaging technologies applied on mussels could be extend the shelf-life of this product. In one study, the initial microbial load of the mussel samples reduced after the pasteurization process. The authors also observed that this reduction was determined not only in the total mesophilic and psychrophilic bacterial count, but also in the the yeast mold counts after pasteurization being 2.44, 2.07 and $2.37 \mathrm{log}$ cfu/g, respectively (Tosun et al., 2018). (Cherifi and Sadok, 2016) reported that total mesophilic bacteria flora for marinated mussels (3.21 log CFU/g) had significantly lower level, when compared to the control sample (4.14 log CFU/g). In the study indicated by (Arcales and Nacional, 2018) that pretreatment using lactic acid could be used to improve the shelf-life of green mussels for 15 days, when compared with 6 days of uncontrolled samples (Arcales and Nacional, 2018). Turan et al. (2008) reported that the shelf-life of mussels smoked by hot smoking and stored at $4 \pm 1^{\circ} \mathrm{C}$ at refrigerator temperature determined as 12 days. The authors reported in another study that the sous-vide cook and chill method at $85^{\circ} \mathrm{C}$ for 10 minutes with or without salt brine resulted in being able to preserve the quality of mussels and extend their shelf-life to 21 storage days (Bongiorno et al., 2018). Turan et al. (2013) stated in their study that mussels in polystyrene plates wrapped with stretch film could be consumed until end of the 2nd day, whereas mussels placed in water in glass jar could be consumed until the end of the 3rd day. In another report; all black mussels retained desirable sensory characteristics during the first 8 days of storage, whereas the modified atmosphere packaged and vacuum packaged mussels exceeded the limit of consumption after 12 days of storage at $2^{\circ} \mathrm{C}$ (Caglak et al., 2008). The consumable period of mussel was found as 12 day and 18 day for MAP and vacuum group, respectively reported by (Turan and Onay, 2015). The effect of modified atmosphere packaging (MAP) on the keeping quality of green mussel stored at $4^{\circ} \mathrm{C}$ was investigated by (Masniyom et al., 2011). In this study the authors reported that MAP with $80 \% \mathrm{CO}_{2}, 10 \% \mathrm{O}_{2}$ and $10 \%$ $\mathrm{N}_{2}$ was determined as the best condition for extending the shelf-life of green mussel (Masniyom et al., 2011). In another report, $80 \% / 20 \% \mathrm{CO}_{2} / \mathrm{N}_{2}$ gas mixture was the most effective for black mussel preservation achieving a shelf-life of 14-15 days reported by (Goulas et al., 2005). Many studies have been done about the shelf-life of un processed and processed mussels stored under refrigerated conditions, which were decribed in the above studies, However very limited study have been found about examining the microbiological quality and safety of frozen mussels (Popovic et al., 2010; Georgescu et al., 2015; Angane et al., 2020). Popovic et al., (2010) reported in their study that the psychrophilic bacteria level of frozen 28 shellfish were determined between the 2-3 log cfu/g and only 2 samples were determined at above $3 \mathrm{log}$ $\mathrm{cfu} / \mathrm{g}$. In our study the avarage value of TPBC of examined 36 frozen black mussel packages was found to be $2.57 \pm 0.09 \mathrm{log}$ cfu/g. Our result was determined well correlated with the above study, which was determined the TPBC of frozen shellfish between the 2-3 log cfu/g.

In our study the avarage value of TMBC of examined 36 frozen black mussel packages was determined to be $2.42 \pm 0.05 \mathrm{log}$ cfu/g. In one study; Georgescu et al. (2015) reported that the TMBC were higher for the mussels of locally harvested samples than frozen mussels. Popovic et al. (2010) also reported that total aerobic mesophilic bacteria level of 26 samples were determined as 5 log cfu/g, only 4 samples were indicated that below the level of $3 \log \mathrm{cfu} / \mathrm{g}$. In contrast to this study (Popovic et al., 2010), in our study TMBC of frozen black mussels were determined lower than total psychrotrophic bacteria counts. However, this study was very similar to our findings about not including pathogenic bacteria of frozen samples. In contrast to the frozen mussel samples, Papadopoulou et al. (2007) reported in their study that pathogenic microorganisms such as E. coli and Listeria spp. could be found at the ratio of $83.3 \%(25 / 30)$ and $3.3 \%(1 / 30)$ in examined raw mussels, respectively.

As a result, frozen black mussels taken from four different markets in Izmir Province of Turkey were determined as acceptable. The TMBC of all frozen black mussels were determined below the upper acceptable microbiological limit indicated as $5.0 \mathrm{log}$ cfu/g according to ICMSF (1992).

The findings also showed that frozen black mussels bought from different markets in the Izmir Province of Turkey were determined as safe for consumption according to the Turkish Food Codex Regulation because pathogenic bacteria such as E. coli, Staphylococcus aureus, Salmonella spp. Listeria monocytogenes, Vibrio spp. were not present in any of the frozen mussel samples.

\section{ACKNOWLEDGEMENT}

This study was a summary of Bülent Kafa's PhD thesis. It was presented at II. International Fisheries Symposium, November 04-08, Girne, Cyprus, 2018. This study was supported by Ege University Scientific Research Projects Coordination Unit. Project Number: 16-BiL-017. 


\section{REFERENCES}

Alvarez-Munoz, D., Rodriguez-Mozaz, S., Jacobs, S., Serra-Compte, A., Caceres, N., Sioen, I., Verbeke, W., Barboso, V., Ferrari, F., FernandezTejedor, M., Cunha, S., Granby, K., Robens, J., Kotterman, M., Marques, A. \& Barcelo, D. (2018). Pharmaceuticals and endocrine disruptors in raw and cooked seafood from European market: Concentrations and human exposure levels. Environment International, 119, 570-581. DOI: 10.1016/j.envint.2018.07.006

Angane, M., Gupta, S., Fletcher, G.C., Summers, G., Hedderley, D.I. \& Quek, S.Y. (2020). Effect of air blast freezing and frozen storage on Escherichia coli survival, n-3 polyunsaturated fatty acid concentration and microstructure of Greenshell ${ }^{\mathrm{TM}}$ mussels. Food Control, 107284. DOI: $10.1016 /$ j.foodcont.2020.107284

Anonymous. (1997). TS EN ISO 11290-1. Gida ve yem maddelerinin mikrobiyolojisi-Listeria monocytogenes'in aranması ve sayımı metodu, Bölüm 1: Arama metodu, 50s.

Anonymous. (2001). TS 6235 EN ISO 6887-1. Gıda ve hayvan yemlerinin mikrobiyolojisi. Deney numunelerinin başlangıç süspansiyonun ve ondalık seyreltilerin hazırlanması için genel kurallar, 17s.

Anonymous. (2005). TS EN ISO 6579, Mikrobiyoloji gıda ve hayvan yemleri Salmonella türlerinin belirlenmesi için yatay yöntem, 30 s.

Anonymous. (2006). TS EN ISO 6888-2/A1. GIda ve hayvan yemlerinin mikrobiyolojisi- koagulaz- pozitif- stafilokokların (Staphylococcus aureus ve diğer türler) sayımı için yatay metot, Bölüm 2: Tavşan fibrinojeni agar besiyeri kullanarak belirlenmesi, $11 \mathrm{~s}$.

Anonymous. (2013). ISO 4833, Horizontal method for the enumaration of microorganism. Colony count technique at $30^{\circ} \mathrm{C}, 32 \mathrm{~s}$.

Anonymous. (2015). TS ISO 7251. GIda ve hayvan yemleri mikrobiyolojisi Muhtemel Escherichia coli'nin belirlenmesi ve sayımı için yatay yöntem En muhtemel sayı tekniği, 22s.

Anonymous. (2016). BAX® System Real-Time PCR Assay for Vibrio. http://www.dupont.com/content/dam/dupont/products-and-services/foodprotection/food-protection-landing/documents/bax_rtvibrio_proddesc.pdf (10.12.2016).

Arcales, J.A.A. \& Nacional, L.M. (2018). Effect of lactic and citric acid pretreatment on quality changes of green mussel (Perna viridis) during chilled storage. Current Research in Nutrition and Food Science, 6(3), 862-872. DOI: 10.12944/CRNFSJ.6.3.29

Arvanitoyannis, I.S. \& Stratakos, A.C. (2010). Effect of Irradiation on fish and seafood In I.S. Arvanitoyannis (Ed.), Irradiation of Commodities (pp.287365).

Bongiorno, T., Tulli, F., Comi, G., Sensidoni, A. \& Andyanto, D. (2018). Sousvide cook-chill mussel (Mytilus galloprovincialis): evaluation of chemical, microbiological and sensory quality during chilled storage $3^{\circ} \mathrm{C}$. LWTFood Science and Technology, 91, 117-124. DOI: 10.1016/j.Iwt.2017.12.005

Caglak, E., Cakli, S. \& Kılınç, B. (2008). Microbiological, chemical and sensory assessment of mussels (Mytilus galloprovincialis) stored under modified atmosphere packaging. European Food Research and Technology, 226, 1293-1299. DOI: 10.1007/s00217-007-0657-1

Cherifi, H. \& Sadok, S. (2016). Effects of marinating process on mussels physicochemicaland microbiological quality attributes during refrigerated storage. Bull. Inst. Natn. Scien. Tech. Mer de Salammbo, 43, 1-17.

Cruz-Romero, M., Kerry, J.P. \& Kelly, A.L. (2008). Changes in the microbiological and physicochemical quality of high-pressure-treated oysters (Crassostrea gigas) during chilled storage. Food Control, 19, 1139-1147. DOI: 10.1016/j.foodcont.2007.12.004

Erkan, N. (2005). Changes in quality characteristics during cold storage of shucked mussels (Mytilus galloprovincialis) and selected chemical decomposition indicators. Journal of Science of Food and Agriculture, 85, 2625-2630. DOI: 10.1002/jsfa.2331

Farady, S.E. (2019). Microplatics as a new, ubiquitous pollutant: Strategies to anticipate management and advise seafood consumers. Marine Policy, 104, 103-107. DOI: 10.1016/j.marpol.2019.02.020

Gamgam, H. \& Altunkaynak, B. (2017). Parametrik olmayan yöntemler, 6. Baskı, Seçkin Yayıncılık. $456 \mathrm{~s}$.

Georgescu, M., Dobrea, M., Neagu, I., Popescu, A.A.D. \& Dojana, R. (2015). Microbiological evaluation of imported frozen mussels and locally harvested Black Sea mussels. Bulletin of University of Agricultural Sciences and Veterinary Medicine Cluj-Napoca. Veterinary Medicine, 72(1), 179-180. DOI: 10.15835/buasvmcn-vm:10346

Goulas, A. E., Chouliara, I., Nessi, E., Kontominas, M.G. \& Savvaidis, I.N. (2005). Microbiological, biochemical and sensory assessment of mussels (Mytilus galloprovincialis) stored under modified atmosphere packaging. Journal of Applied Microbiology, 98(3), 752-760. DOI: 10.1111/j. 1365-2672.2004.02512.x

Hallström, E., Bergman, K., Mifflin, K., Parker, R., Tyedmers, P., Troell, M. \& Ziegler, F. (2019). Combined climate and nutritional performance of seafoods. Journal of Cleaner Production, 230, 402-411. DOI: 10.1016/j.jclepro.2019.04.229

Huss, H.H. (1997). Control of indigenous pathogenic bacteria in seafood. Food Control, 8, 91-98. DOI: 10.1016/S0956-7135(96)00079-5

Jovic, M. \& Stankovic, S. (2014). Human exposure to trace metals and possible public health risks via consumption of mussels Mytilus galloprovincialis from the Adriatic coastal area. Food Chemistry Toxicology, 70, 241-251.

DOI: 10.1016/j.fct.2014.05.012

Kılınç, B. \& Besler, A. (2014). The occurrence of enteric bacteria in marine environment and pollution. Marine Science Technology Bulletin, 3, 3943.

Kılınç, B., Şen Yılmaz, B. \& Gören, B. (2018). İzmir'in farklı bölgelerinde satışa sunulan midye dolmaların mikrobiyolojik kalitesi. Süleyman Demirel Üniversitesi Eğirdir Su Ürünleri Fakültesi Dergisi, 14(4), 276290. DOI: $10.22392 /$ egirdir.403570

Kocatepe, D., Taskaya, G., Turan, H. \& Kaya, Y. (2016). Microbiological investigation of wild, cultivated mussels (Mytilus galloprovincialis L. 1819) and stuffed mussels in Sinop-Turkey. Ukrainian Food Journal, 5(2), 299-305. DOI: 10.24263/2304-974X-2016-5-2-9

Kocatepe, D., Keskin, I. \& Kaya, Y. (2019). The effect of frying-the chemical, microbiological, and acrylamide composition of mussels as a street Food. Journal of Aquatic Food Product Technology, 28(1), 117-128. DOI: $10.1080 / 10498850.2018 .1563260$

Lampila, L.E. \& McMillin, K.W. (2012). Major microbial hazards associated with packaged seafoods. Advances in Meat, Poultry and Seafood Packaging, 891, 59-85. DOI: 10.1533/9780857095718.1.59

Liu, Q., Liao, Y. \& Shou, L. (2018). Concentration and potential health risk of heavy metals in seafoods collected from Sanmen Bay and its adjacent areas, China. Marine Pollution Bulletin, 131, 356-364.

DOI: 10.1016/j.marpolbul.2018.04.041

Lund, E.K. (2013). Health benefits of seafoods; Is it just the fatty acids? Food Chemistry, 140, 413-420. DOI: 10.1016/j.foodchem.2013.01.034

Manousaridis, G., Nerantzaki, A., Paleologos, E.K., Tsiotsias, A., Savvaidis, I.N. \& Kontominas, M.G. (2005). Effect of ozone on microbial, chemical and sensory attributes of shucked mussels. Food Microbiology, 22, 1-9. DOI: 10.1016/j.fm.2004.06.003

Masniyom, P., Benjama, O. \& Maneesri, J. (2011). Extending the shelf-life of refrigerated green mussel (Perna viridis) under modified atmosphere packaging. Songklanakarin Journal of Science and Technology, 33(2), 171-179.

Nicolas, J., Hoogenboom, R.A.L.P., Hendriksen, P.J.M., Bodero, M., Bovee, T.F.N., Rietjens, I.M.C.M. \& Gerssen, A. (2017). Marine biotoxins and associated outbreaks following seafood consumption: Prevention and surveillance in the $21^{\text {st }}$ century. Global Food Security, 15, 11-21. DOI: 10.1016/j.gfs.2017.03.002

Odeyemi, O.A., Burke, C.M., Bolch, C.J.S. \& Stanley, R. (2018). Evaluation of spoilage potential and volatile metabolites production by Shewanella baltica isolated from modified atmosphere packaged live mussels. Food Research International, 103, 415-425. DOI: 10.1016/j.foodres.2017.10.068

Okpola, C.O.R. (2014). Investigation of quality attributes of ice-stored Pacific white shrimp (Litopenaeus vannamei) as affected by sequential minimal ozone treatment. LWT-Food Science and Technology, 57, 538-547. DOI: $10.1007 / s 00003-014-0904$ 
Papadopoulou, C., Economou, E., Zakas, G., Salamoura, C., Dontorou, C. \& Apostolou, J. (2007). Microbiological and pathogenic contaminants of seafood in Greece. Journal of Food Quality, 30(1), 28-42. DOI: 10.1111/j.1745-4557.2007.00104.x

Popovic, N.T., Skukan, B.A., Dzidara, P. \& Rakovac, R.C. (2010). Microbiological quality of marketed fresh and frozen seafood caught off the Adriatic coast of Croatia. Veterinarni Medicina, 55, 233-241. DOI: 10.17221/2997-VETMED

Ripabelli, G., Sammarco, M.L., Grasso, G.M., Fanelli, I., Caprioli, A. \& Luzzi, I. (1999). Occurrence of Vibrio and other pathogenic bacteria in Mytilus galloprovincialis (mussels) harvested from Adriatic Sea, Italy. International Journal of Food Microbiology, 49, 43-48. DOI: 10.1016/S0168-1605(99)00056-2

Robert-Pillot, A., Copin, S., Himber, C., Gay, M. \& Quilici, M.L. (2014). Occurence of the three major Vibrio species pathogenic for human in sefood products consumed in France using Real-Time PCR. International Journal of Food Microbiology, 189, 75-81. DOI: 10.1016/j.ijfoodmicro.2014.07.014

Spiller, P., Hibbeln, J.R., Myers, G., Vannice, G., Golding, J., Crawford, M.A., Strain, J.J., Connor, S.L., Brenna, J.T., Kris-Etherton, P., Holub, B.J., Harris, W.S., Lands, B., Mcnamara, R.K., Tlusty, M.F., Salem Jr. N. \& Carlson, S.E. (2019). An abundance of seafood consumption studies presents new apportunities to evaluate effects on neurocognitive development. Prostaglandis, Leukotrienes and Essential Fatty Acids 151, 8-13. DOI: 10.1016/j.plefa.2019.10.001

Tahergorabi, R. \& Jaczynski, J. (2016). Seafood proteins and human health. In: S. Raatz, D. Bibus (Ed.), Fish and Fish oil in Health and Disease Prevention (pp.323-331). DOI: 10.1016/B978-0-12-802844-5.00029-4
Tosun, Ş.Y., Alakavuk, D.Ç. \& Ulusoy, Ş. (2018). Quality changes of thermal pasteurized mussels (Mytilus galloprovincialis) during refrigerated storage at $4 \pm 1^{\circ} \mathrm{C}$, Aquatic Sciences and Engineering, 33(4), 117-123. DOI: 10.26650/ASE2018428669

Turan, H., Sönmez, G., Çelik, M.Y., Yalçın, M. \& Kaya, M. (2008). The effects of hot smoking on the chemical composition and shelf life of Mediterranean mussel (Mytilus galloprovincialis L. 1819) under chilled storage. Journal of Food Processing and Preservation, 32, 912-922. DOI: 10.1111/j.1745-4549.2008.00221.x

Turan, H., Kocatepe, D., Altan, C.O. \& Erkoyuncu, İ. (2013). Soğukta saklanan midyelerin Mytilus galloprovincialis L. 1819 raf ömrünün belirlenmesi. Akademik Gıda, 11(3), 47-51.

Turan, H. \& Onay, R.T. (2015). Modifiye atmosfer paketleme uygulanan midyelerin (Mytilus galloprovincialis, Lamarck 1819) buzdolabı $\left(4 \pm 2^{\circ} \mathrm{C}\right)$ koşullarında raf ömrünün tespiti. Journal of Food and Health Science, 1(4), 185-198. DOI: 10.3153/JFHS15018

Witte, B.D., Devriese, L., Bekaert, K. \& Hoffman, S. (2014). Quality assessment of the blue mussel (Mytilus edulis): Comparison between commercial and wild types. Marine Pollution Bulletin, 85, 146-155. DOI: 10.1016/j.marpolbul.2014.06.006

Zahelyazkov, G., Yankovska-Stefanova, T., Mineva, E., Stratev, D., Vashin, I., Dospatliev, L., Valkova, E. \& Popova, T. (2018). Risk assessment of some heavy metals in mussels (Mytilus galloprovincialis) and veined rapa whelks (Rapana venosa) for human health. Marine Pollution Bulletin, 128, 197-201. DOI: 10.1016/j.marpolbul.2018.01.024 